7 Lee W, Jones L, Goodman R, Heyman I. Broad outcome measures may underestimate effectiveness: an instrument comparison study. Child Adolesc Ment Health 2005; 10: 143-4.

8 Garralda ME, Rose G, Dawson R. Measuring outcomes in a child psychiatry in-patient unit. J Children's Services 2009; in press.
9 Zwaanswijk M, Verhaak PFM, van der Ende J, Bensing JM, Verhulst FC. Change in children's emotional and behavioural problems over a one-year period. Eur Child Adolesc Psychiatry 2006; 15: 127-31.

10 Andrade AR, Lambert W, Bickman L. Dose effect in child psychotherapy: outcomes associated with negligible treatment. J Am Acad Child Adolesc Psychiatry 2000; 39: 161-8.

\title{
Themes: part 1
}

\section{Henry R. Rollin}

In this, the first of two contributions, Henry Rollin presents a digest of some of the themes explored in his long-running ' 100 years ago' series. A full-length article on this topic is available as an online supplement to this item.

\section{Overcrowding in asylums}

The clamour for admissions to the ever-increasing number of beds in the already overcrowded asylum continued. Those who queued outside the gates were both genuine psychiatric cases and an assortment of social misfits. A doctor employed in one of these therapeutically stagnant human warehouses described it thus:

'They are houses for the detention of the insane, but one really cannot describe them for the treatment of mental diseases.' (Lancet, 21 January 1905)

\section{Classification of mental diseases (nosology)}

Pioneers in the field at this time (alienists) were French, the two most important being Phillippe Pinel (1745-1826) and his pupil, Jean-Etienne Esquirol (1772-1840). The latter is particularly important for his Des Maladies Mentales, which transformed the nosology of mental diseases. The French were succeeded by German-speaking doctors, i.e. Emil Kraepelin (1886-1926) and Richard von Krafft-Ebbing (1840-1902) whose Textbook of Insanity was glowingly reviewed in England (BMJ, 15 July 1905).

\section{The professional status of psychiatry}

In the pecking order of medical disciplines, psychiatrists were firmly seated below the salt. The Cinderella status of psychiatry is well described here (BMJ, 23 April 1898):

'The bane of alienism in the past has been its isolation from general medicine. So long as the treatment of mental disease is restricted to separate institutions set apart for the purpose, so long will endure the foolish prejudice that a stigma of disgrace and of horror attached to it.'

\section{The Medico-Psychological Association (MPA)}

By 1901, the MPA had attracted a mere 616 members (swollen by 1925 to a derisory 673!). To conduct its affairs, it rented a woefully inadequate room, albeit in one of the most fashionable and expensive quarters in London W1.

In essence, the MPA was a cosy dining club which met periodically in noted restaurants in London. The scientific meetings were poor in quality and badly attended. Even AGMS - for example, one held on 11 May 1899 - drew a mere 50.

Politically, the MPA was virtually impotent: if advice was sought concerning legislative matters, it was Big Brother, the Royal College of Physicians that was consulted.

\section{Beginning of improvement in the social and legal status of 'pauper lunatics'}

Dorset was the first county in England to take advantage of Section CCLV of the Lunacy Act 1890, by providing accommodation of private patients within the corpus of the County Institution (BMJ, January 1902).

However, Dorset's claim was challenged by the LCC (Journal of Mental Science, April 1900) where there is an account of provision for 60 female patients at Horton Hospital, Epsom, and the same provision to be had at Claybury and in other counties for the poorer class of private patients.

Nevertheless, it is important to stress that these more privileged patients were still 'certified', whereas, in Scotland, by this time, there was provision for voluntary (VP) admission. This giant step forward was noted in the BMJ 4 Jan 1902. (Voluntary patients were first admitted in England and Wales under the Mental Treatment Act 1930.)

\section{Innovation, or lack of it, in treatment in psychiatry}

The paucity of attendance at clinical meetings of the MPA is probably explained by the mediocrity of the programmes offered. For example, one such meeting was illuminated by a paper read by Dr J A Gilmour on 'Value of rectal saline in certain cases of mental diseases' (Lancet, 23 April 1904). Another (Lancet, 24 November 1900) describes a paper on the 'Application of electricity in certain forms of mental diseases' (a harbinger of ECT?).

In stark contrast, however, is the advent of the successful treatment of what would be described today as myxoedematous madness, by the prescription of thyroid extract. It adds a rider: 'these cases must not be sent to an asylum in error as it can be treated outside' (Lancet, 23 April 1904).

One of the most important events to trouble the stagnant waters of psychiatry at this time was the eruption of Freudianism and psychoanalysis. Dr Havelock Ellis was one of the early British psychiatrists to accept at least some of Freud's revolutionary concepts and it was to him, therefore, that editors of learned journals and books turned to review Freud's writings. Thus, it fell to Ellis to review one of the most important of Freud's major books, the Psychopathology of Everyday Life (1907) in the Journal of Mental Science, October 1907. His review aroused criticism to which Ellis replies:

'Such criticism, however, by no means destroys the value of Freud's work, which cannot but be attractive to those whose business is to search beneath the surface of human speech and conduct for underlying causes.'

I am tempted to include one of Freud's brilliant aphorisms: that in psychotherapy 'it turns hysterical misery into ordinary human unhappiness'. 